\title{
Botanical management of Rhizoctonia solani in soybean
}

\author{
S.P. PATOLE*, R.S. SALUNKHE AND A.D. PHAPALE
}

Department of Plant Pathology, Mahatma Phule Krishi Vidyapeeth, Rahuri, AHMEDNAGAR (M.S.) INDIA

\section{ARITCLE INFO}

Received : 24.07 .2016

Revised : 07.09.2016

Accepted : 21.09.2016

KEY WORDS :

Soybean, Rhizoctonia solani, Botanical

*Corresponding author:

Email : santoshpatole57@ rediffmail.com

\section{ABSTRACT}

Soybean is one of the important most pulse and oilseed crops grown all over the world. The root rot disease of soybean caused by Rhizoctonia solani is generally found in the soybean growing area in Maharashtra state. The present investigation was undertaken to study effects of botanical extract on root rot of soybean under glass house condition from pot culture experiment in glass house, it was found that the minimum PDI was observed in seed treatment with botanical extracts viz., Zingiber officinale L. (31.48) followed by Allium sativum L. (35.18) and Azardirachta indica (40.18)

How to view point the article : Patole, S.P., Salunkhe, R.S. and Phapale, A.D. (2016). Botanical management of Rhizoctonia solani in soybean. Internat. J. Plant Protec., 9(2) : 561-565, DOI : 10.15740/HAS/IJPP/9.2/561-565. 